\title{
Effects of High-Temperature Milk Processing
}

\author{
Hilton C. Deeth
}

check for

updates

Citation: Deeth, H.C. Effects of High-Temperature Milk Processing Encyclopedia 2021, 1, 1312-1321. https://doi.org/10.3390/ encyclopedia1040098

Academic Editor: Victoria Samanidou

Received: 14 November 2021 Accepted: 14 December 2021 Published: 17 December 2021

Publisher's Note: MDPI stays neutral with regard to jurisdictional claims in published maps and institutional affiliations.

Copyright: (C) 2021 by the author. Licensee MDPI, Basel, Switzerland. This article is an open access article distributed under the terms and conditions of the Creative Commons Attribution (CC BY) license (https:/ / creativecommons.org/licenses/by/ $4.0 /)$.
School of Agriculture and Food Sciences, University of Queensland, Brisbane, QLD 4072, Australia; h.deeth@uq.edu.au; Tel.: +61-429-007-050

Definition: In this entry, high temperature is defined as 90 to $150^{\circ} \mathrm{C}$. Many dairy processes, including extended shelf-life (ESL) and ultra-high-temperature (UHT) processing, in-container sterilization, yogurt milk heat treatment, pre-heating or forewarming milk for production of sterile concentrated milk and powders, manufacture of co-precipitate and dolce de leche, involve heat treatments in this temperature range. Pasteurization is not included in this entry as it is generally performed at $72-75{ }^{\circ} \mathrm{C}$.

Keywords: heat treatment; UHT; sterilization; ESL; Maillard; denaturation; cross-linking; vitamins; furosine; lactulose

\section{Introduction}

Thermal treatments of milk in the temperature range of 90 to $150{ }^{\circ} \mathrm{C}$ cause a range of effects on the components of milk, many of which affect the nature and quality of processed milk and dairy products. The bacteriological and chemical changes and the practical consequences of the chemical changes are discussed in this entry.

The various heat treatments in the $90-150{ }^{\circ} \mathrm{C}$ range used in the dairy industry have their individual objectives. These are primarily bacteriological but, in some cases also chemical. As examples, ESL processing aims to destroy all bacteria which are likely to grow at low temperatures (because ESL milk is stored under refrigeration) and UHT processing is designed to destroy bacteria which are likely to grow at ambient temperatures [1] which can be up to $\geq 40{ }^{\circ} \mathrm{C}$ [2]. However, all heat treatments in this temperature range cause chemical changes which may or may not have consequences for the final products.

\section{Bacteriological Effects}

Most non-spore-forming bacteria are inactivated at temperatures below $90{ }^{\circ} \mathrm{C}$, although some thermoduric bacteria, e.g., some coryneforms, can survive heating at $90{ }^{\circ} \mathrm{C}$ for $10 \mathrm{~min}$ [3]. However, the main focus of thermotolerant bacteria in milk is on the sporeforming bacteria. Smelt and Brul [4] reported that the heat stability of bacterial spores ranges from $<1 \mathrm{~min}$ at $90^{\circ} \mathrm{C}$ for Clostridium botulinum Type E to $3-4 \mathrm{~min}$ at $130{ }^{\circ} \mathrm{C}$ for Geobacillus stearothermophilus.

The sporeformers relevant to milk can be categorized as psychrotrophic, mesophilic, and thermophilic [5]. While these terms apply to the growth temperatures of the bacteria, the order of the heat resistance of their spores is roughly of the same order, i.e., psychrotrophic < mesophilic < thermophilic. Spores of psychrotrophic bacteria are most significant in ESL-milk which is processed at $125-140{ }^{\circ} \mathrm{C}$ for $1-10 \mathrm{~s}$ [6], commonly around $127{ }^{\circ} \mathrm{C}$ for $5 \mathrm{~s}$ [7] and stored under refrigeration. Therefore, spores that survive ESL heat treatment and can grow at low temperatures can cause spoilage of ESL milk. A heat treatment of, or equivalent to, $134^{\circ} \mathrm{C}$ for $4 \mathrm{~s}$ inactivates these spores [8]. Common psychrotrophic sporeformers are Bacillus species such as B. coagulans and B. circulans but some strains of others, e.g., B. cereus and Paenibacillus species, are also psychrotrophic. B. cereus is a potential problem in ESL as some psychrotrophic strains are pathogenic [8].

The majority of sporeformers that contaminate milk are mesophilic. They include mostly Bacillus species such as B. licheniformis, B. subtilus, B. pumilus and B. megaterium. Their 
spores are inactivated by standard UHT treatments of $135-150{ }^{\circ} \mathrm{C}$ for $1-10 \mathrm{~s}$ [6], commonly $138-140{ }^{\circ} \mathrm{C}$ for $\sim 4 \mathrm{~s}$. Thermophilic spores include highly-heat-resistant spores (HRS), some of which can survive UHT processing. HRS are mainly of B. sporothermodurans and G. stearothermophilus. Spores of the former have been reported to have decimal reduction values ( $D$-values) at $140{ }^{\circ} \mathrm{C}$ of $\sim 5.0 \mathrm{~s}[9,10]$ and require UHT holding conditions of $148^{\circ} \mathrm{C}$ for $10 \mathrm{~s}$ or $150{ }^{\circ} \mathrm{C}$ for $6 \mathrm{~s}$ to achieve a reasonable level of inactivation of these spores in milk [11]. In-container sterilization treatments of $110-120^{\circ} \mathrm{C}$ for $10-20 \mathrm{~min}$ [6] are the most intense heat treatments applied to milk. They are designed to inactivate all bacteria, including spores.

The bactericidal effect of a given thermal sterilizing process can be expressed as an $F_{0}$-value or a $B^{*}$-value. $F_{0}$ has traditionally been used for in-container (retort) sterilization and is based on a reference temperature of $121{ }^{\circ} \mathrm{C}$ (actually $121.11^{\circ} \mathrm{C}$ or $250{ }^{\circ} \mathrm{F}$ ) and a $z$-value ( $z$-value is the increase in temperature required to cause a 10 -fold decrease (1-log) in $D$-value where $D$-value is the time required to cause a 10 -fold reduction $(1-\log )$ in the bacterial count) of $10^{\circ} \mathrm{C}$. $F_{0}$ of 1 is equivalent to heating at $121^{\circ} \mathrm{C}$ for $1 \mathrm{~min}$. The minimum heating conditions for producing a safe low-acid food has been arbitrarily established to be equivalent to $F_{0}$ of 2.6 (usually rounded up to 3.0); this is the "botulinum cook" which causes a $12-\log$ reduction of spores of $C$. botulinum, assuming a $D$-value at $121^{\circ} \mathrm{C}$ of $13 \mathrm{~s}$ [12]. Most commercial retort processes of low-acid foods operate at $F_{0}$-values considerably in excess of 3.

Since the reference temperature for the $F_{0}$-value is outside the range used for UHT processing, an alternative index, the $B^{*}$-value was introduced. $B^{*}$ is based on a reference temperature of $135^{\circ} \mathrm{C}$ and a $z$-value of $10.5^{\circ} \mathrm{C}$. $B^{*}$ of 1 equates to heating at $135^{\circ} \mathrm{C}$ for $10.1 \mathrm{~s}$, (or equivalent conditions such as $145.5^{\circ} \mathrm{C}$ for $1 \mathrm{~s}$ ). These cause a 9-log reduction of thermophilic spores [13] and are the recommended minimum conditions for UHT processing. Most UHT processes have $B^{*}$-values of $>1$; a survey of 23 Australian UHT plants revealed a range of $B^{*}$-values from 1.6 to 16.5 [14]. $B^{*}$ of 1 is approximately equivalent to $F_{0}$ of 4 . Therefore, the recommended minimum conditions for UHT processing are more severe than those for in-container sterilization and represent a considerable food safety margin in terms of inactivating C. botulinum.

Table 1 shows the effects on a range of parameters, including $B^{*}$ and $F_{0}$, of heating at $90-150{ }^{\circ} \mathrm{C}$ for $10 \mathrm{~s}$. It demonstrates clearly that heating at $90-110^{\circ} \mathrm{C}$ has little or no effect on $F_{0}$ and $B^{*}$. In terms of UHT processing, the normal pre-heat section, which usually operates at $90-95^{\circ} \mathrm{C}$ for $30-120 \mathrm{~s}$, and the later cooling stage makes no contribution to these parameters. Conversely, it shows that heating at $140^{\circ} \mathrm{C}$ for $10 \mathrm{~s}$ exceeds the recommended minimum values for $B^{*}$ and $F_{0}$. Table 1 also shows the effect of a typical in-container sterilization process on $F_{0}$ and $B^{*}$ and shows the $F_{0}$-value (7.76) to be in excess of the accepted minimum of 3.0.

Table 1. Effect of holding time and temperature on a range of parameters (the effects of the heat-up to, and cool-down from these temperatures were not included in the calculations).

\begin{tabular}{|c|c|c|c|c|c|c|c|c|}
\hline $\begin{array}{l}\text { Temp. } \\
\left({ }^{\circ} \mathrm{C}\right)\end{array}$ & $B^{*}$ & $F_{0}$ & $C^{*}$ & $\begin{array}{c}\beta \text {-Lg } \\
\text { Denaturation }^{1} \\
\text { (Cumulative) }\end{array}$ & $\begin{array}{c}\alpha \text {-La } \\
\text { Denaturation }^{1} \\
\text { (Cumulative) }\end{array}$ & $\begin{array}{c}\text { Browning }^{2} \\
\text { (Equivalent Time } \\
\text { [s] at } 121^{\circ} \mathrm{C} \text { ) }\end{array}$ & $\begin{array}{c}\text { Lactulose }^{3} \\
\text { (mg/kg Milk) }\end{array}$ & $\begin{array}{c}\text { Furosine } \\
\text { (mg/100 g } \\
\text { Protein) }\end{array}$ \\
\hline \multicolumn{9}{|c|}{$10 \mathrm{~s}$ holding } \\
\hline 90 & 0 & 0 & 0.01 & 29.1 & 1.8 & 0.66 & 0.4 & 0.49 \\
\hline 100 & 0 & 0 & 0.03 & 40.2 & 3.2 & 1.6 & 1.5 & 1.02 \\
\hline 110 & 0 & 0.1 & 0.05 & 51.7 & 5.6 & 3.8 & 4.6 & 2.06 \\
\hline 120 & 0.04 & 0.13 & 0.11 & 62.3 & 9.5 & 9.3 & 13.3 & 4.0 \\
\hline 130 & 0.33 & 1.29 & 0.23 & 71.4 & 15.7 & 22.3 & 37.1 & 7.5 \\
\hline 140 & 2.96 & 12.94 & 0.47 & 78.8 & 24.2 & 53.6 & 98 & 13.8 \\
\hline 150 & 26.7 & 129.4 & 0.98 & 84.4 & 35.9 & 129.2 & 247 & 24.9 \\
\hline \multicolumn{9}{|c|}{10 min holding } \\
\hline 120 & 2.21 & 7.76 & 6.55 & 99.98 & 99.73 & 555 & 80 & 236 \\
\hline
\end{tabular}


Table 2 shows the contribution of the various stages of a UHT plant to $F_{0}$ and $B^{*}$. In a plant with the temperature-time profile shown in Figure 1 and in tabular form in Table 2, heating up to $122^{\circ} \mathrm{C}$ and cooling down from $75^{\circ} \mathrm{C}$ make little or no contribution to $F_{0}$ and $B^{*}$.

Table 2. Effect of various heating and cooling sections of a UHT plant on a range of parameters.

\begin{tabular}{|c|c|c|c|c|c|c|c|c|c|c|}
\hline \multicolumn{2}{|c|}{$\begin{array}{c}\text { Temperature } \\
\left({ }^{\circ} \mathrm{C}\right)\end{array}$} & \multirow{2}{*}{$\begin{array}{l}\text { Time in } \\
\text { Section (s) }\end{array}$} & \multirow[t]{2}{*}{$B^{*}$} & \multirow[t]{2}{*}{$F_{0}$} & \multirow{2}{*}{$C^{*}$} & \multirow{2}{*}{$\begin{array}{c}\beta-\mathrm{Lg} \\
\text { Denat'n }^{1}\end{array}$} & \multirow{2}{*}{$\begin{array}{c}\alpha \text {-La } \\
\text { Denat'n }^{1}\end{array}$} & \multirow{2}{*}{$\begin{array}{c}\text { Browning }^{2} \\
\text { (Equivalent Time } \\
\text { [s] at } 121^{\circ} \mathrm{C} \text { ) }\end{array}$} & \multirow{2}{*}{$\begin{array}{c}\text { Lactulose }^{3} \\
\text { (mg/kg } \\
\text { Milk) }\end{array}$} & \multirow{2}{*}{$\begin{array}{c}\text { Furosine }^{4} \\
\text { (mg/100 g } \\
\text { Protein) }\end{array}$} \\
\hline In & Out & & & & & & & & & \\
\hline 5 & 95 & 33.0 & 0.00 & 0.00 & 0.01 & 12.11 & & 0.44 & 0.3 & \\
\hline 95 & 95 & 60.0 & 0.00 & 0.00 & 0.10 & 76.54 & & 6.17 & 4.9 & 5.24 \\
\hline 95 & 122 & 16.0 & 0.02 & 0.05 & 0.09 & 83.13 & 8.76 & 6.77 & 8.7 & 8.55 \\
\hline 122 & 138 & 23.0 & 1.22 & 4.97 & 0.55 & 91.45 & 38.42 & 55.65 & 94.7 & 34.55 \\
\hline 138 & 138 & 4.0 & 0.76 & 3.27 & 0.16 & 92.33 & 44.23 & 18.00 & 32.4 & 39.37 \\
\hline 138 & 75 & 25.0 & 0.35 & 1.41 & 0.22 & 93.69 & 53.26 & 20.60 & 30.9 & 49.91 \\
\hline 75 & 25 & 33.0 & 0.00 & 0.00 & 0.00 & 93.69 & 53.26 & 0.00 & 0.00 & 49.91 \\
\hline \multirow[t]{2}{*}{25} & 25 & 0.0 & 0.00 & 0.00 & 0.00 & 93.69 & 53.26 & 0.00 & 0.00 & 49.91 \\
\hline & & 194 & 2.34 & 9.70 & 1.14 & 93.69 & 53.26 & 107.63 & 171.9 & 49.91 \\
\hline
\end{tabular}

Based on kinetics of: ${ }^{1}$ [15]; ${ }^{2}[16] ;{ }^{3}[17] ;{ }^{4}[18]$. $\beta$-Lg and $\alpha$-La denaturation values are cumulative with time of processing. Denat' $n$ is an abbreviation for denaturation.

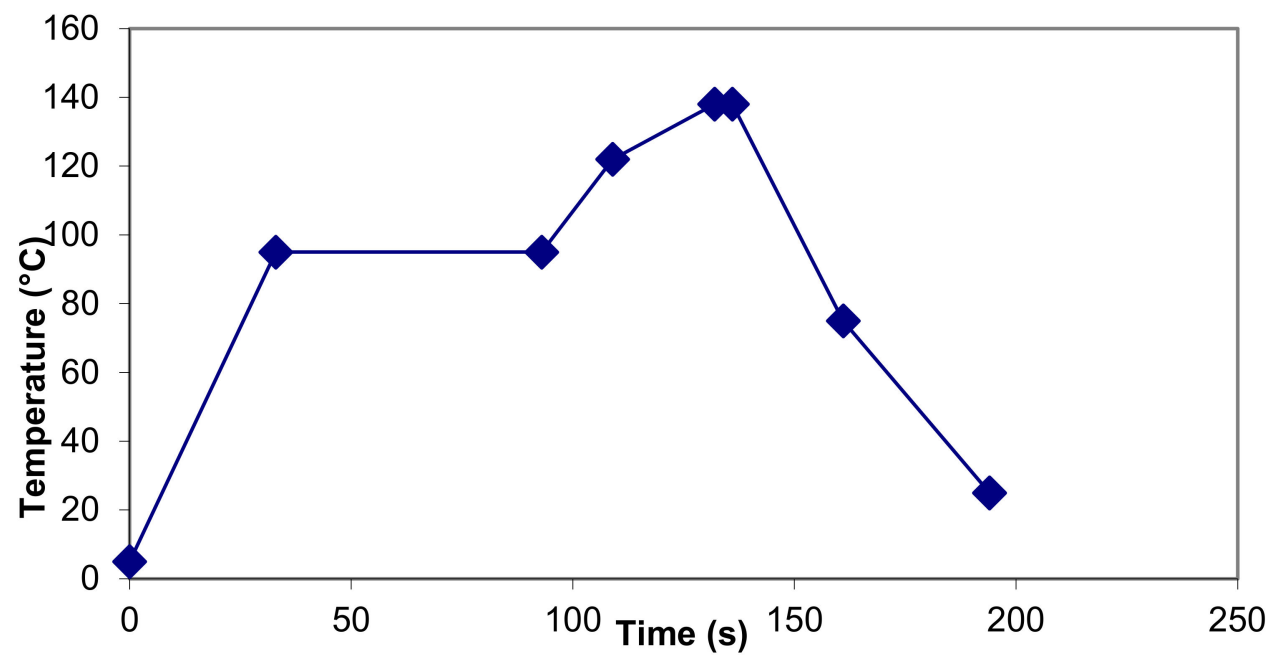

Figure 1. Temperature time profile for UHT plant for which parameters in Table 2 were calculated.

\section{Chemical Effects}

\subsection{Effect on Caseins}

Caseins are much more heat-stable than whey proteins so the majority of effects of heat on proteins concern whey proteins. At the normal $\mathrm{pH}$ of milk, $\sim 6.7$, the caseins in regular milk coagulate after heating at $140{ }^{\circ} \mathrm{C}$ for about $20 \mathrm{~min}$. In concentrated milk, the proteins are less stable and coagulate at a lower temperature. Heat stability tests are performed at $140{ }^{\circ} \mathrm{C}$ for single-strength milk and $120^{\circ} \mathrm{C}$ for concentrated milk.

One effect of heat on casein is the release of $\mathrm{k}$-casein from the casein micelle. On heating milk at $90{ }^{\circ} \mathrm{C}$ for $15 \mathrm{~min}$ at $\mathrm{pH} 6.7$, about $30 \%$ of the $\mathrm{k}$-casein is released into the milk serum from the casein micelle [19]. In the milk serum, it forms complexes with whey proteins.

High-temperature heat treatment causes protein cross-linking mainly involving caseins. This occurs through two different mechanisms: via dehydroalanine (produced from alanine, cysteine or phosphoserine by $\beta$-elimination) or via dicarbonyl Maillard reaction products such as glyoxal and methyl glyoxal. Cross-linking via dehydroalanine produces isodipeptides such as lysinoalanine (LAL) and histidinoalanine through reaction with 
lysine and histidine, respectively. Some cross-linking occurs during normal UHT heating but more occurs during in-container sterilization [20]. Reported levels of LAL, in mg/kg, in UHT milk are up to 400 , in autoclaved milk up to 880 , and in sodium caseinate up to 1530 [21]. LAL also increases in UHT milk during storage [22]. The level of LAL in sodium caseinate is high because LAL formation is favored at high $\mathrm{pH}$ and alkali is used in the preparation of caseinate.

After heating milk with and without lactose at $95{ }^{\circ} \mathrm{C}$ for $8 \mathrm{~h}$, Al-Saadi et al. [23] concluded that cross-linking in milk products containing lactose occurs mainly via Maillard reaction products, and in milk products with no lactose, occurs via dehydroalanine.

\subsection{Effect on Whey Proteins}

The major whey proteins of relevance during heating in the $90-150{ }^{\circ} \mathrm{C}$ range are $\beta$-lactoglobulin $(\beta-\mathrm{Lg})$ and $\alpha$-lactalbumin $(\alpha$-La). This is because, together, they represent $\sim 80 \%$ of the whey proteins in milk ( $\beta-\mathrm{Lg}, \sim 60 \% ; \alpha-\mathrm{La}, \sim 20 \%$ ) and because they are more heat-stable than the next most abundant whey proteins, bovine serum albumin and immunoglobulins. $\beta$ - $\operatorname{Lg}$ and $\alpha$-La begin to denature at $\sim 70{ }^{\circ} \mathrm{C}$ and hence their heat-induced changes at $>90^{\circ} \mathrm{C}$ are significant for many milk products. With heat, $\beta$-Lg unfolds and exposes previously masked sulfhydryl groups and hydrophobic sections of the peptide chain. Both the sulfhydryl groups and the hydrophobic sections of $\beta$-Lg can then interact with other whey proteins and caseins. The sulfhydryl groups interact with disulfide bonds (and sulfhydryl groups after heat-induced scission of disulfide bonds) to form aggregates, mainly $\beta$-Lg- $\beta$-Lg, $\beta$-Lg- $\alpha$-La, $\beta$-Lg-K-casein and $\beta$-Lg- $\alpha$-La-K-casein [24].

The kinetics of denaturation of $\beta$ - $\mathrm{Lg}$ and $\alpha$-La change quite dramatically at $90-100{ }^{\circ} \mathrm{C}$; the $z$-values are much higher at $>100^{\circ} \mathrm{C}$ than they are at $<90^{\circ} \mathrm{C}$, meaning that the reaction rate is much less dependent on temperature $>100{ }^{\circ} \mathrm{C}$.

\subsection{Inactivation of Enzymes}

Milk contains a wide range of enzymes with varying heat stabilities [25]. Of the major indigenous enzymes in milk, lipoprotein lipase, lactoperoxidase, alkaline phosphatase and xanthine oxidase are inactivated at temperatures $<90{ }^{\circ} \mathrm{C}$ while acid phosphatase and three proteases (plasmin, plasminogen activators and cathepsin D) are inactivated at temperatures $>90^{\circ} \mathrm{C}$. Some minor enzymes, lysozyme, sulfhydryl oxidase and ribonuclease also retain activity after heating at $90^{\circ} \mathrm{C}$.

The most significant heat-resistant milk enzymes are plasmin and plasminogen activators. Plasminogen, the precursor of plasmin, has a similar heat stability to that of plasmin. An interesting feature of the thermal stability of plasmin and plasminogen is that their $z$-values, i.e., sensitivity to rise in temperature, change at $\sim 90^{\circ} \mathrm{C}: \sim 8.5^{\circ} \mathrm{C}$ at $60-90{ }^{\circ} \mathrm{C}$ and $\sim 80^{\circ} \mathrm{C}$ at $90-140{ }^{\circ} \mathrm{C}[26]$.

Fresh raw milk contains a mixture of plasmin and plasminogen, with the latter being converted to plasmin by indigenous proteolytic plasminogen activators. Active plasmin can cause serious defects such as bitterness and age gelation in UHT milk and hence inactivation of it and plasminogen during processing is important. Fortunately, it can be inactivated in the preheat section of UHT plants at $90-95^{\circ} \mathrm{C}$ for $\geq 30 \mathrm{~s}[27,28]$, more readily than in the high-heat sections; this is due to the change in heat sensitivity at $\sim 90{ }^{\circ} \mathrm{C}$ as mentioned above.

Some bacterial enzymes, mainly proteases and lipases, which are produced by psychrotrophic bacteria in raw milk, are very heat-stable and can survive UHT processing conditions (135-145 ${ }^{\circ} \mathrm{C}$ for $\left.1-10 \mathrm{~s}\right)$. While the parent bacteria are killed by heat treatments such as pasteurization $\left(72-75^{\circ} \mathrm{C}\right.$ for $\left.15-30 \mathrm{~s}\right)$, their enzymes survive and cause quality problems in stored milk and milk products, particularly UHT milk. The proteases cause bitterness and gelation while the lipases cause rancidity. The enzymes are produced when the bacterial count of the raw milk exceeds $\sim 10^{6} \mathrm{cfu} / \mathrm{mL}$ [3].

As an indication of the heat stability of the bacterial proteases, $D$-values at 130, 140 and $150{ }^{\circ} \mathrm{C}$ of 4.9, 2.2 and $0.93 \mathrm{~min}$, respectively, for Pseudomonas fluorescens biotype I proteases 
have been reported [29]. Similarly, Christen et al. [30] found that many of the lipases survived heating at $138^{\circ} \mathrm{C}$ for $15 \mathrm{~s}$ but, in general, were not as stable as the proteases.

\subsection{Practical Consequences of the Effect on Milk Proteins}

- An effect of the release of $\mathrm{k}$-casein from the micelle by heat is that it removes a proportion of the negative charge from the micelles and makes them more susceptible to coalescence. This has been proposed as an important factor in sedimentation and age gelation in UHT milk [31].

- Preheat conditions in UHT plants $\left(90-95{ }^{\circ} \mathrm{C}\right.$ for $\left.\geq 30 \mathrm{~s}\right)$ are designed to denature the whey proteins to reduce fouling and also to cause plasmin inactivation [26] by complexation with $\beta$-Lg through sulfhydryl-disulfide interactions [32].

- The standard heating conditions for yogurt manufacture are $90-95^{\circ} \mathrm{C}$ for $\sim 5 \mathrm{~min}$. This results in $70-80 \%$ denaturation of whey proteins $(\sim 99 \%$ of $\beta-\mathrm{Lg})$. The denaturation and the concomitant interaction of $\beta$-Lg with $\mathrm{k}$-casein increases the viscosity of the milk and helps to give yogurt a stable body [33].

- The heating of milk causes an increase in reactive or free sulfhydryl groups due to their unmasking during the unfolding of $\beta-\mathrm{Lg}$. The level of reactive sulfhydryls increases with the severity of heating and has been used as a measure of the severity of heat treatments, provided the milk is analyzed soon after processing; the level decreases during storage due to oxidation, particularly at room temperature [34].

- Heating milk at $>90{ }^{\circ} \mathrm{C}$ such as in UHT processing, also results in a cooked flavor which is attributable to volatile sulfur compounds produced by the degradation of whey proteins, chiefly $\beta-\mathrm{Lg}$, and the proteins of the milk fat globule membrane. The compounds formed include hydrogen sulfide, which disappears during storage of UHT milk for about a week, hydrogen sulfide, methanethiol, dimethyl sulfide, dimethyl sulfoxide, carbon disulfide and dimethyl disulfide [35].

- In a study of the effects of various heat treatments on the production of cooked flavor, Gaafar [36] found that it was first detected by panellists when the milk was heated at $94{ }^{\circ} \mathrm{C}$ for $20 \mathrm{~s}$. This corresponded to $\sim 60 \%$ denaturation of $\beta$-Lg. This fact, together with bacteriological considerations, was used in determining the optimum conditions for ESL processing [9]; heating at $134^{\circ} \mathrm{C}$ for $4 \mathrm{~s}$ is sufficient for the inactivation of psychrotrophic spores and causes $\sim 56 \%$ denaturation of $\beta$ - $\mathrm{Lg}$, ensuring minimal cooked flavor.

- The extent of whey protein denaturation is the basis of the Whey Protein Nitrogen Index (WPNI) used for distinguishing low-heat-, medium-heat-, and high-heat skim milk powders. The WPNI, the amount of undenatured whey protein, for these powders is, respectively, $\geq 6.00,1.51-5.99$ and $\leq 1.50 \mathrm{mg} W P N \cdot \mathrm{g}^{-1}$ powder. Typical processing conditions for these powders are $72-80{ }^{\circ} \mathrm{C}$ for $15-30 \mathrm{~s}, 90^{\circ} \mathrm{C}$ for $30 \mathrm{~s}$ and $90{ }^{\circ} \mathrm{C}$ for $5 \mathrm{~min}$. The classification of the powders determines their most suitable application. For example, medium-heat powders are used in confectionary, bakery products and recombined milk while high-heat powders are ideal for use in recombined evaporated and sweetened condensed milk.

- Whole milk powder is produced from milk heated at $90-95^{\circ} \mathrm{C}$ for $30-60 \mathrm{~s}$. These conditions are designed to denature whey proteins and produce antioxidant sulfhydryls to protect the fat in the powder from oxidation during storage.

- Whey protein denaturation has a major role in fouling of UHT heat exchangers. Fouling deposits in the UHT plant where temperatures are between 95 and $110^{\circ} \mathrm{C}$ (known as Type A deposits) are largely composed of whey proteins. Deposits at higher temperatures are predominantly mineral with some casein. It has been hypothesized that maximum fouling occurs when $\beta$ - $L g$ is in the denatured, non-aggregated moltenstate form when it is "sticky" and readily attaches to the stainless-steel wall and other deposits. Fouling can be minimized when preheat conditions are severe enough to minimise the time the whey proteins spend in this "sticky" state [37]. 
- Heating milk at $\sim 90{ }^{\circ} \mathrm{C}$ for $30 \mathrm{~min}$ with calcium ions (and sometimes acid) to denature the whey proteins and complex them with casein, causes the formation of the product, co-precipitate. Co-precipitate contains almost all of the proteins in milk [38] (pp. 476-477).

- Pre-heating, or fore-warming, is an integral part of most sterilizing procedures for concentrated milk. This prolongs the storage life of the product by retarding the development of structure leading to viscosity increase and gelation. Various temperature-time combinations (e.g., $100{ }^{\circ} \mathrm{C}$ for $17 \mathrm{~min}$ [39]; $120^{\circ} \mathrm{C}$ for $3 \min$ [40]; $117^{\circ} \mathrm{C}$ for $2 \mathrm{~min}$ [41]; and $135^{\circ} \mathrm{C}$ for $15 \mathrm{~s}$ [42]) have been used but all are designed to denature most of the whey proteins.

- High-temperature heat treatment has an adverse effect on rennet coagulation and hence cheese is not produced from high-heat-treated milk. Milk heated at $140{ }^{\circ} \mathrm{C}$ forms either a very weak coagulum or none at all with rennet. The effect has been attributed to the denaturation of whey proteins and their interaction with the casein micelle, inhibiting aggregation of the micelles. The impairment of rennet coagulation occurs when more than $60 \%$ of the whey proteins are denatured. The first stage of rennet action, the proteolysis stage is not affected but the second stage, the aggregation stage is affected. The casein-derived peptide (CMP) resulting from proteolysis of $k$-casein differs after high heat treatment; it contains less glycosylated form as the denatured whey proteins influence the release of the glycosylated more than the non-glycosylated form of CMP.

- Another effect of high heat treatment which can affect rennet coagulation is the deposition of calcium phosphate on the micelle. This occurs because the solubility of calcium phosphate decreases with heating at high temperatures.

\subsection{The Maillard Reaction}

The Maillard reaction is initiated by the interaction of a reducing sugar with amino acids, chiefly lysine, of the proteins. In milk, the reducing sugar is almost always lactose, although in lactose-hydrolysed products it also includes glucose and galactose. Several subsequent reactions occur which produce a range of products that can have marked effects on the flavor and color of some products.

Browning is the most noticeable effect, which is due to the formation of melanoidins in the final stage of the Maillard reaction. It occurs during heating if the heating is quite severe. For example, freshly processed UHT milk does not have a noticeable brown color but sterilized milk does. As illustrated in Table 2, very little browning is caused in sections of the featured UHT plant below $122{ }^{\circ} \mathrm{C}$.

An exception to the severe heating criterion is the heating of lactose-hydrolysed milk where both the galactose and glucose are more active in the Maillard reaction than lactose. The Maillard reaction continues during storage where it is more significant than during heat processing; however, this aspect is beyond the scope of this entry.

Practical Consequences of the Maillard Reaction in Milk

- The first major stable product of the Maillard reaction in milk is the (protein-bound) Amadori product, lactulosyl-lysine. This product has assumed significance because when it is acid digested it forms furosine which is commonly used as a chemical heat index for freshly processed UHT milk.

- The Maillard reaction causes a loss of available lysine as it becomes nutritionally unavailable when combined with lactose in, for example, lactulosyl-lysine. The percentage of lysine that is blocked depends on the heat treatment applied (and storage temperature and time); for example, the percentage for UHT milk is up to $10 \%$ and for in-container sterilized milk it is up to $15 \%$. Infant formulae with a high percentage of whey protein (usually $\sim 60 \%$ of the protein) have relatively high levels, $25-30 \%$. However, the nutritive value of these products is not substantially diminished as the amount of available lysine is still high [43]. 
- It has been reported that heating unmodified milk at $121{ }^{\circ} \mathrm{C}$ for $400 \mathrm{~s}$ is required before browning can be detected by eye [44]. In the illustration of a commercial UHT process in Figure 1 and Table 2, the browning value has been estimated to reach the equivalent of only $107.6 \mathrm{~s}$ at $121{ }^{\circ} \mathrm{C}$, well below the reported threshold value. However, in Table 1 , the estimated browning for an in-container sterilization process is equivalent to $555 \mathrm{~s}$ at $121^{\circ} \mathrm{C}$, which exceeds the published threshold.

- Dulce de leche is a golden brown, viscous, sweet milk product. It has been traditionally produced by concentrating milk, with added sucrose (and sometimes with added glucose), in heated open kettles over several hours until the solids content is around $70 \%$. Its color, which is one of its defining features, is due to Maillard browning, chiefly through lactose but also glucose when added [45].

- Sweetened condensed milk has a creamy yellow color. A brown color in this product is considered a defect. It can occur if the sucrose used contains some invert sugar (hydrolysed to glucose and fructose) which is more Maillard-reactive than sucrose [46].

- Protein cross-linking can occur via Maillard reaction products such as glyoxal and methyl glyoxal. Such cross-linking may contribute to the loss of solubility of milk powders such as milk protein concentrate in which the Maillard reaction is known to proceed during storage of the powder [47].

- $\quad$ Some advanced Maillard reaction products are also known (especially in medical fields) as advanced glycation end-products (AGEs). A major one formed in milk is carboxymethyl-lysine (CML) which is sometimes used as a marker of AGEs. It is formed by cleavage of lactulosyl-lysine. AGEs such as CML are significant medically as they are ingested with food and absorbed along with endogenous AGEs which occur naturally in the body of healthy people. They have been implicated in the progression of diseases such as diabetes but the exact significance of dietary AGEs is still unclear [43,48].

\subsection{Effect on Carbohydrates}

In addition to its reaction with proteins in Maillard reactions, lactose is epimerized by heat to lactulose, a galactose-fructose disaccharide. A wide range of lactulose levels have been reported for UHT and in-container sterilized milk. The levels in directly processed milk are lower than those for indirectly processed milk. Andrews and Morant [49] reported a range for UHT milk of $99-715 \mathrm{mg} / \mathrm{L}$ and for in-container sterilized milk of $570-1730 \mathrm{mg} / \mathrm{L}$.

Galactose levels in milk increase with the severity of heat treatment. The levels in raw, UHT and in-container sterilized milk were 7.1, 12.5 and $21.2 \mathrm{mg} / 100 \mathrm{~mL}$. In-container sterilization but not UHT processing results in the formation of tagatose, 3-deoxypentulose and epilactose [50,51].

\section{Practical Consequences of the Effect on Carbohydrates}

- Lactulose is not present in raw milk and is present in heated milk. Its level in milk increases with the severity of heat treatment. Furthermore, lactulose increases very little during storage of UHT milk. These facts mean that it is an ideal chemical heat index.

- Lactulose is a laxative and is used as for treating constipation. However, the levels in heated milk are unlikely to have a laxative effect.

- Because tagatose, 3-deoxypentulose and epilactose are present in in-container sterilized milk but not UHT milk, they may be used to distinguish between these two milk types $[50,51]$. The galactose levels may also be useful as an indicator of the severity of heat treatment [51].

\subsection{Effect on Vitamins}

Fat-soluble vitamins are affected very little by the high-heat treatment of milk. The water-soluble vitamins are affected with the effect increasing with the severity of the 
heating. For example, for UHT milk, Burton [52] reported losses of $0-10 \%$ for all watersoluble vitamins apart from folic acid and vitamin C which had losses of 15 and 24\%, respectively. The losses of most water-soluble vitamins in in-container sterilized milk were $0-30 \%$ and for folic acid, cobalamine and vitamin C, they were $50,<90$ and $90 \%$. The losses of folic acid and vitamin $C$ are greater during storage due to oxidation by dissolved oxygen.

Practical Consequence of the Effect on Vitamins

- The destruction of water-soluble vitamins reduces the nutritive value of the product. This is significant for the most intense heating only.

- The destruction of thiamine (vitamin B1) is the basis of the chemical index $C^{*}$ proposed by Kessler and Horak [13] as a measure of the severity of heat treatment. $C^{*}$ can be determined by using the reference temperature of $135^{\circ} \mathrm{C}$, and the z-value is $31.4{ }^{\circ} \mathrm{C}$. The formula for $C^{*}$ (at constant temperature) is $10^{(T-135) / 31.4)} \times t / 30.5$. $C^{*}$ of 1 is equivalent to a $3 \%$ destruction in thiamine, which relates to heating at $135^{\circ} \mathrm{C}$ for 30.5 $\mathrm{s}$, or equivalent conditions such as $140^{\circ} \mathrm{C}$ for $21 \mathrm{~s}$; this is the recommended maximum severity for a UHT process [14] although many commercial UHT plants operate at $C^{*}$ of $>1$ [14]. Table 2 shows a commercial UHT plant with a $C^{*}$ of $1.2,90 \%$ of which was attributable to sections at $>122{ }^{\circ} \mathrm{C}$, Direct UHT plants generally have $C^{*}$ of $<1$ while the $C^{*}$ for in-container sterilization is much higher; the plant depicted in Table 1 has a $C^{*}$ of 6.55 .

Funding: This research received no external funding.

Institutional Review Board Statement: Not applicable.

Informed Consent Statement: Not applicable.

Conflicts of Interest: The author declares no conflict of interest.

Entry Link on the Encyclopedia Platform: https://encyclopedia.pub/18458.

\section{References}

1. Deeth, H. Heat treatment of milk: Extended shelf life (ESL) and ultra-high-temperature (UHT) treatments. In Encyclopedia of Dairy Sciences, 3rd ed.; McNamara, J., McSweeney, P., Eds.; Academic Press: London, UK, 2021; Volume 4, pp. 618-631.

2. Deeth, H.C.; Lewis, M.J. High Temperature Processing of Milk and Milk Products; Wiley Blackwell: Oxford, UK, 2017; ISBN 978-1-118-46050-4.

3. Abd-el-Malek, Y.; Gibson, T. Studies in the bacteriology of milk. 3. The Corynebacteria of milk. J. Dairy Res. 1952, 19, 153-159. [CrossRef]

4. Smelt, J.P.P.M.; Brul, S. Thermal inactivation of microorganisms. Crit. Rev. Food Sci. Nutr. 2014, 54, 1371-1385. [CrossRef] [PubMed]

5. McGuiggan, J.T.M.; McCleery, D.R.; Hannan, A.; Gilmour, A. Aerobic spore-forming bacteria in bulk raw milk: Factors influencing the numbers of psychrotrophic, mesophilic and thermophilic Bacillus spores. Int. J. Dairy Technol. 2002, 55, 100-107. [CrossRef]

6. Deeth, H.C.; Smithers, G. Heat Treatment of Milk—Overview. IDF Factsheet 2018, 001/2018/02. Available online: https: / / fil-idf.org/wp-content/uploads/2018/02/Factsheet-001_Heat-treatment-1-1.pdf (accessed on 10 November 2021).

7. Mayr, R.; Gutser, K.; Busse, M.; Seiler, H. Indigenous aerobic sporeformers in high heat treated $\left(127^{\circ} \mathrm{C}, 5 \mathrm{~s}\right)$ German ESL (extended shelf life) milk. Milchwiss. Milk Sci. Int. 2004, 59, 143-146.

8. Deeth, H.C. Extended shelf-life milk thermal processing. Encyclopedia 2021. Available online: https:/ /encyclopedia.pub/13160 (accessed on 10 November 2021).

9. Huemer, I.A.; Klijn, N.; Vogelsang, H.W.J.; Langeveld, L.P.M. Thermal death kinetics of spores of Bacillus sporothermodurans isolated from UHT milk. Int. Dairy J. 1998, 8, 851-855. [CrossRef]

10. Scheldeman, P.; Herman, L.; Foster, S.; Heyndrickx, M. Bacillus sporothermodurans and other highly heat-resistant spore formers in milk. J. Appl. Microbiol. 2006, 101, 542-555. [CrossRef]

11. Hammer, P.; Lembke, F.; Suhren, G.; Heesschen, W. Characterization of a heat-resistant mesophilic Bacillus species affecting the quality of UHT milk. In Heat Treatments and Alternative Methods; IDF Document 9602; International Dairy Federation: Brussels, Belgium, 1996; pp. 9-16.

12. Stumbo, C.R.; Murphy, J.R.; Cochran, J. Nature of thermal death time curves for PA-3679 and Clostridium botulinum. Food Technol. 1950, 4, 321-326. 
13. Kessler, H.G.; Horak, P. [Objective assessment of UHT treatment of milk by standardization of bacteriological and chemical effects.] Objektive Beurteilung der UHT-Milcherhitzung durch Normierung bakteriologischer und chemischer Effekte. Milchwiss. Milk Sci. Int. 1981, 36, 129-133.

14. Tran, H.; Datta, N.; Lewis, M.J.; Deeth, H.C. Predictions of some product parameters based on the processing conditions of ultra-high-temperature milk plants. Int. Dairy J. 2008, 18, 939-944. [CrossRef]

15. Lyster, R.L.J. The denaturation of a-lactalbumin and b-lactoglobulin in heated milk. J. Dairy Res. 1970, 37, 233-243. [CrossRef]

16. Horak, F.P.; Kessler, H.G. [Colour measurement as an indicator of heat-treatment of foods, as exemplified by milk products.] Die Farbmessung als Indikator hitzebehandelter Lebensmittel am Beispiel von Milchprodukten. Z. Lebensm. Technol. Verfahr. 1981, 32, 180-184.

17. Rombaut, R.; Dewettinck, K.; De Mangelaere, G.; Huyghebaert, A. Inactivation of heat resistant spores in bovine milk and lactulose formation. Milchwiss. Milk Sci. Int. 2002, 57, 432-436.

18. Claeys, W.L.; Ludikhuyze, L.R.; Hendrickx, M.E. Formation kinetics of hydroxymethylfurfural, lactulose and furosine in milk heated under isothermal and non-isothermal conditions. J. Dairy Res. 2001, 68, 287-301. [CrossRef]

19. Anema, S.G. On heating milk, the dissociation of kappa-casein from the casein micelles can precede interactions with the denatured whey proteins. J. Dairy Res. 2008, 75, 415-421. [CrossRef]

20. Fritsch, R.J.; Hoffmann, H.; Klostermeyer, H. Formation of lysinoalanine during heat treatment of milk. Z. Lebensm. Unters. Forsch. 1983, 176, 341-345.

21. Friedman, M. Chemistry, biochemistry, nutrition, and microbiology of lysinoalanine, lanthionine, and histidinoalanine in food and other proteins. J. Agric. Food Chem. 1999, 47, 1295-1319. [CrossRef]

22. Al-Saadi, J.M.S.; Deeth, H.C. Cross-linking of proteins and other changes in UHT milk during storage at different temperatures. Aust. J. Dairy Technol. 2008, 63, 93-99.

23. Al-Saadi, J.M.S.; Easa, A.M.; Deeth, H.C. Effect of lactose on cross-linking of milk proteins during heat treatments. Int. J. Dairy Technol. 2013, 66, 1-6. [CrossRef]

24. Wijayanti, H.B.; Bansal, N.; Deeth, H.C. Stability of whey proteins during thermal processing: A review. Compr. Rev. Food Sci. Food Saf. 2014, 13, 1235-1251. [CrossRef]

25. Deeth, H.C. Heat-induced inactivation of enzymes in milk and dairy products. A review. Int. Dairy J. 2021, 121, 105104. [CrossRef]

26. Saint Denis, T.; Humbert, G.; Gaillard, J.L. Heat inactivation of native plasmin, plasminogen and plasminogen activators in bovine milk: A revisited study. Lait 2001, 81, 715-729. [CrossRef]

27. Newstead, D.F.; Paterson, G.; Anema, S.G.; Coker, C.J.; Wewala, A.R. Plasmin activity in direct-steam-injection UHT-processed reconstituted milk: Effects of preheat treatment. Int. Dairy J. 2006, 16, 573-579. [CrossRef]

28. Rauh, V.M.; Johansen, L.B.; Ipsen, R.; Paulsson, M.; Larsen, L.B.; Hammershoj, M. Plasmin activity in UHT milk: Relationship between proteolysis, age gelation, and bitterness. J. Agric. Food Chem. 2014, 62, 6852-6860. [CrossRef]

29. Kroll, S.; Klostermeyer, H. Heat inactivation of exogenous proteinases from Pseudomonas fluorescens. I. Possibility of inactivation in milk. Z. Lebensm. Unters. Forsch. 1984, 179, 288-295. [CrossRef]

30. Christen, G.L.; Wang, W.C.; Ren, T.J. Comparison of the heat resistance of bacterial lipases and proteases and the effect on ultra-high temperature milk quality. J. Dairy Sci. 1986, 69, 2769-2778. [CrossRef]

31. Anema, S.G. Age gelation, sedimentation, and creaming in UHT milk: A review. Compr. Rev. Food Sci. Food Saf. 2019, 18, 140-166. [CrossRef]

32. Kelly, A.L.; Foley, J. Proteolysis and storage stability of UHT milk as influenced by milk plasmin activity, plasmin/betalactoglobulin complexation, plasminogen activation and somatic cell count. Int. Dairy J. 1997, 7, 411-420. [CrossRef]

33. Tetra Pak. Dairy Processing Handbook; Tetra Pak Processing Systems: Lund, Sweden, 2003; p. 247.

34. Patrick, P.S.; Swaisgood, H.E. Sulfhydryl and disulfide groups in skim milk as affected by direct ultra-high-temperature heating and subsequent storage. J. Dairy Sci. 1976, 59, 594-600. [CrossRef]

35. Al-Attabi, Z.; D'Arcy, B.R.; Deeth, H.C. Volatile sulfur compounds in pasteurised and UHT milk during storage. Dairy Sci. Technol. 2014, 94, 241-253. [CrossRef]

36. Gaafar, A.M.M. Investigation into the Cooked Flavor in Heat-Treated Milk. Ph.D. Thesis, University of Reading, Reading, UK, 1987.

37. Grijspeerdt, K.; Mortier, L.; De Block, J.; Van Renterghem, R. Applications of modelling to optimise ultra-high temperature milk heat exchangers with respect to fouling. Food Control 2004, 15, 117-130. [CrossRef]

38. Walstra, P.; Geurts, T.J.; Noomen, A.; Jellema, A.; van Boekel, M.A.J.S. Dairy Technology. Principles of Milk Properties and Processes; Marcel Dekker: New York, NY, USA, 1999.

39. Leviton, A.; Pallansch, J. High temperature-short time sterilized evaporated milk. IV. The retardaion of gelation with condensed phosphates, manganous ions, polyhydric compounds, and phosphatides. J. Dairy Sci. 1962, 45, 1045-1056. [CrossRef]

40. De Koning, P.J.; Kaper, J.; Rollema, H.S.; Driessen, F.M. Age-thinning and gelation in unconcentrated and concentrated UHTsterilized skim milk. Effect of native milk proteinase. Neth. Milk Dairy J. 1985, 39, 71-87.

41. Schmidt, D.G. Electron-microscopic studies on gelation of UHTST sterilized concentrated skim milk. Neth. Milk Dairy J. 1968, 22, 40-49.

42. Nieuwenhuijse, J.A. Changes in heat-treated milk products during storage. In Heat-Induced Changes in Milk, 2nd ed.; Fox, P.F., Ed.; International Dairy Federation: Brussels, Belgium, 1995; pp. 231-255. 
43. Mehta, B.M.; Deeth, H.C. Blocked lysine in dairy products: Formation, occurrence, analysis, and nutritional implications. Compr. Rev. Food Sci. Food Saf. 2016, 15, 206-218. [CrossRef]

44. Fink, R.; Kessler, H.G. Comparison of methods for distinguishing UHT treatment and sterilization of milk. Milchwiss. Milk Sci. Int. 1988, 43, 275-280.

45. Vargas, M.O.; Prestes, A.A.; Miotto, M.; Prudencio, E.S. Dulce de leche: Product types, production processes, quality aspects and innovations. Int. J. Dairy Technol. 2021, 74, 262-276. [CrossRef]

46. Nieuwenhujse, J.A. Sweetened condensed milk. In Encyclopedia of Dairy Sciences, 2nd ed.; Fuquay, J.W., Fox, P.F., McSweeney, P.L.H., Eds.; Academic Press: London, UK, 2011; Volume 1, pp. 869-873.

47. Le, T.T.; Holland, J.W.; Bhandari, B.; Alewood, P.F.; Deeth, H.C. Direct evidence for the role of Maillard reaction products in protein cross-linking in milk powder during storage. Int. Dairy J. 2013, 31, 83-91. [CrossRef]

48. Barbosa, J.H.P.; Oliveira, S.L.; Seara, L.T.E. The role of advanced glycation end-products (AGEs) in the development of vascular diabetic complications. Arq. Bras. Endocrinol. Metabol. 2008, 52, 940-950. [CrossRef]

49. Andrews, G.R.; Morant, S.V. Lactulose content, colour and the organoleptic assessment of ultra-heat treated and sterilized milks. J. Dairy Res. 1987, 54, 493-507. [CrossRef]

50. Olano, A.; Calvo, M.M.; Corzo, N. Changes in the carbohydrate fraction of milk during heating processes. Food Chem. 1989, 31, 259-265. [CrossRef]

51. Troyano, E.; Villamiel, M.; Olano, A.; Sanz, J.; MartinezCastro, I. Monosaccharides and myo-inositol in commercial milks. J. Agric. Food Chem. 1996, 44, 815-817. [CrossRef]

52. Burton, H. Ultra High Temperature Processing of Milk and Milk Products; Elsevier Applied Science Publishers: New York, NY, USA, 1988. 